\title{
Peran Kader PKK dalam Mengelola Sampah Plastik Rumah Tangga melalui Penerapan Reduce, Reuse, Recycle, Replace, dan Replant.
}

\author{
Hani Damayanti Aprilia ${ }^{1, *}$, Ita Prihantika², Mediya Destalia ${ }^{3}$, Jeni Wulandari ${ }^{4}$ \\ 1,3,4 IImu Administrasi Bisnis, Universitas Lampung, Bandar Lampung, 35145, Lampung, Indonesia \\ 2 Ilmu Administrasi Negara, Universitas Lampung, Bandar Lampung, 35145, Lampung, Indonesia
}

\begin{abstract}
Abstrak.
Tujuan pengabdian ini adalah memberikan pengetahuan, pemahaman, dan keterampilan kepada masyarakat melalui Kader PKK dalam mengelola sampah plastik rumah tangga melalui penerapan Reduce, Reuse, Recycle, Replace, dan Replant. Metode yang digunakan adalah dengan pelatihan dan praktek/simulasi. Target jangka panjang yang akan dicapai dalam kegiatan ini adalah menjadikan Kader PKK mampu mengelola sampah plastik rumah tangga melalui penerapan Reduce, Reuse, Recycle, Replace, dan Replant, sehingga jumlah sampah plastik yang dihasilkan rumah tangga keluarga berkurang jumlahnya. Secara keseluruhan nilai rata-rata peserta sebelum dilaksanakan kegiatan sosialisasi adalah 50,29 dan mengalami kenaikan menjadi 84,93 setelah dilaksanakan kegiatan pelatihan. Kenaikan rata-rata sebesar 34,64 poin. Nilai pre-test tertinggi adalah 80 dan nilai terendah 27, sedangkan untuk sesi post-test nilai tertinggi adalah 100 dan nilai terendah 33. Berdasarkan hasil tersebut, maka dapat disimpulkan bahwa kegiatan pengabdian ini mampu memberikan dampak positif secara kognitif terhadap pengetahuan tentang Reduce, Reuse, Recycle, Replace, dan Replant. Sedangkan dari sisi afektif, kesadaran, kemauan, dan kemampuan peserta dalam menerapkan konsep Reduce, Reuse, Recycle, Replace, dan Replant dalam mengelola sampah plastik rumah tangga dalam kehidupan sehari-hari.
\end{abstract}

Kata kunci.

kader PKK, sampah plastik, 5R.

\section{PENDAHULUAN}

Sampah plastik telah menjadi permasalahan yang kompleks di masyarakat, mulai dari jumlahnya sampai dengan pengelolaan dan pengolahannya. Berat timbunan sampah di Indonesia secara nasional mencapai 200 ribu ton per hari atau setara dengan 73 juta ton per tahun. Sampah-sampah tersebut berasal dari rumah tangga, kawasan komersial, fasilitas publik, sekolah, kantor, jalan, dan sebagainya [1].

Menurut Deputi IV Bidang Pengelolaan Bahan Berbahaya, Beracun, Limbah Bahan Berbahaya dan Beracun, dan Sampah, bahwa paling dominan sampah di Indonesia berasal

* Corresponding author: hani.damayanti@fisip.unila.ac.id

Received 17 November 2020; Received in revised form 27 November 2020; Accepted 7 Desember 2020

Available online 24 Desember 2020

Lembaga Penelitian dan Pengabdian Kepada Masyarakat

Universitas Lampung 
dari sampah rumah tangga, yaitu sebanyak $48 \%$ [1]. Sebab, sebagian besar aktivitas dimulai dari rumah. Ibu rumah tangga sebagai penanggung jawab dalam aktivitas kegiatan di rumah harus pandai dalam menyikapi masalah sampah ini.

Berdasarkan hasil studi di tahun 2008 yang dilakukan di beberapa kota seperti yang dikutip oleh bisnis.com, prosentase pola pengelolaan sampah di Indonesia menurut Rasio adalah:

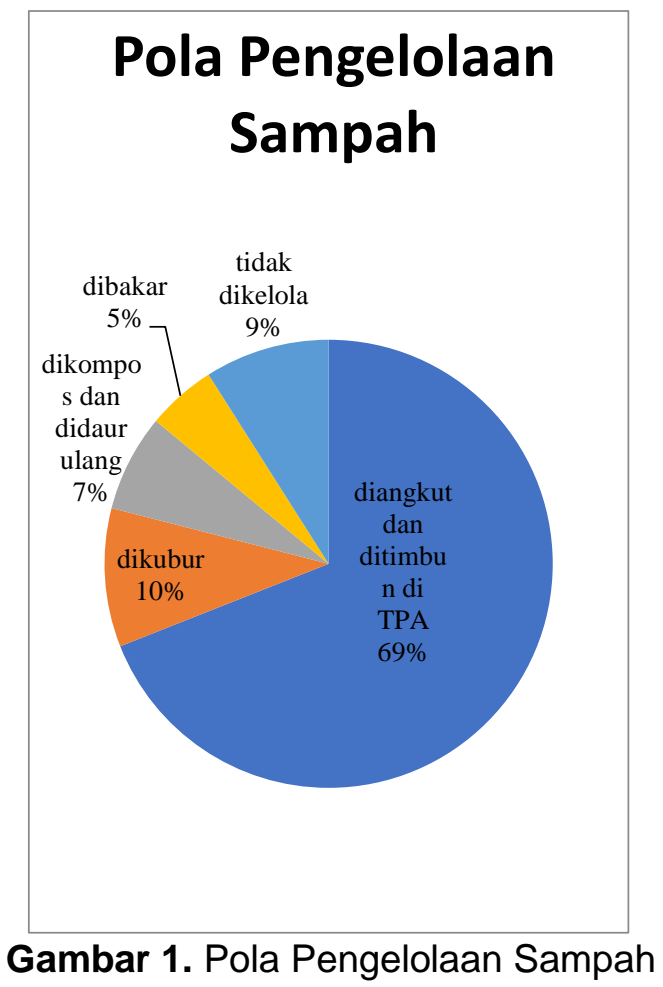

Hasil pemetaan awal ini secara umum selaras dengan fenomena di Indonesia, misalnya hasil penelitian Riswan et al [2].

Berbagai penelitian sebelumnya menguatkan kesimpulan awal tim pengabdian, bahwa keberhasilan pengelolaan sampah sangat ditentukan oleh partisipasi aktif ibu rumah tangga. Sebab, ibu rumah tangga merupakan anggota keluarga yang secara langsung berhubungan dengan masalah sampah baik di dalam maupun di luar rumah tangganya. Oleh karena itu, masalah sampah menjadi tanggung jawab ibu rumah tangga yang sangat berkompeten terhadap kebersihan, kerapian dan keindahan baik di dalam maupun di luar rumah [3].

Adanya peran sentral ibu rumah tangga dalam pengelolaan sampah, maka pembekalan pengetahuan mengenai pengelolaan sampah bagi ibu rumah tangga perlu digalakkan. Hal ini sejalan dengan dengan penelitian [4].

Melalui Kader PKK yang merupakan perpanjangan tangan pemerintah dan notabene adalah para ibu rumah tangga, diharapkan dapat menjadi motor penggerak dalam upaya pemerintah mengkampanyekan konsep zero waste dalam menangani masalah sampah di Indonesia. Peran Kader PKK sebagai motor penggerak pengelolaan sampah plastik rumah tangga, juga sejalan dengan penelitian [5].

Melalui penerapan Reduce, Reuse, Recycle, Replace, dan Replant dalam pengelolaan sampah plastik rumah tangga diharapkan jumlah sampah plastik dapat ditekan, terutama yang berasal dari rumah tangga. Diharapkan tidak hanya bagi dirinya sendiri, akan tetapi Kader PKK diharapkan dapat mengedukasi dan menggerakkan para ibu lainnya dalam menerapkan Reduce, Reuse, Recycle, Replace, dan Replant dalam pengelolaan sampah plastik rumah tangga. 
Merujuk pada hasil pemetaan awal dan penelitian-penelitian terdahulu, maka tim melakukan kegiatan pengabdian kepada masyarakat dengan tujuan meningkatkan keterampilan para Kader PKK dalam menerapkan Reduce, Reuse, Recycle, Replace, dan Replant dalam mengelola sampah plastik rumah tangga di Kelurahan Yosodadi, Metro Timur.

Adapun permasalahan, strategi dan luaran kegiatan pengabdian sebagaimana tercantum pada tabel 1 berikut ini.

Tabel 1. Matriks Permasalahan, Strategi dan Luaran Kegiatan.

\begin{tabular}{|c|c|c|}
\hline Permasalahan Mitra & Strategi & Luaran \\
\hline $\begin{array}{l}\text { Belum meratanya pengetahuan } \\
\text { tentang pengelolaan sampah } \\
\text { plastik rumah tangga }\end{array}$ & $\begin{array}{l}\text { Pemberian materi tentang } \\
\text { pengelolaan sampah plastik rumah } \\
\text { tangga }\end{array}$ & $\begin{array}{l}\text { Meningkatnya pengetahuan } \\
\text { tentang pengelolaan sampah } \\
\text { plastik rumah tangga }\end{array}$ \\
\hline $\begin{array}{l}\text { Belum meratanya pengetahuan } \\
\text { tentang Reduce, Reuse, } \\
\text { Recycle, Replace, dan Replant }\end{array}$ & $\begin{array}{l}\text { Pemberian materi tentang Reduce, } \\
\text { Reuse, Recycle, Replace, dan } \\
\text { Replant }\end{array}$ & $\begin{array}{l}\text { Meningkatnya pengetahuan } \\
\text { tentang Reduce, Reuse, } \\
\text { Recycle, Replace, dan Replant }\end{array}$ \\
\hline $\begin{array}{l}\text { Belum meratanya kemampuan } \\
\text { menerapkan Reduce, Reuse, } \\
\text { Recycle, Replace, dan Replant } \\
\text { dalam mengelola sampah } \\
\text { plastik rumah tangga }\end{array}$ & $\begin{array}{l}\text { Pemberian materi dan } \\
\text { praktek/simulasi penerapan } \\
\text { Reduce, Reuse, Recycle, Replace, } \\
\text { dan Replant dalam mengelola } \\
\text { sampah plastik rumah tangga }\end{array}$ & $\begin{array}{l}\text { Meningkatnya pengetahuan dan } \\
\text { kemampuan dalam menerapkan } \\
\text { Reduce, Reuse, Recycle, } \\
\text { Replace, dan Replant dalam } \\
\text { mengelola sampah plastik } \\
\text { rumah tangga }\end{array}$ \\
\hline
\end{tabular}

\section{METODE}

Prosedur kerja yang akan dilaksanakan dalam kegiatan pengabdian ini dibagi menjadi 5 tahapan, antara lain:

a. Koordinasi dengan Tim Kader PKK. Pelaksanaan koordinasi ini dilakukan maksimal 2 minggu setelah diumumkan diterimanya proposal kegiatan pengabdian ini. Koordinasi meliputi penyebaran surat undangan, persiapan lokasi, dan penyediaan peralatan yang dibutuhkan untuk mendukung kegiatan.

b. Persiapan materi pelatihan dan pendampingan. Materi disusun oleh tim pelaksana kegiatan dalam bentuk softcopy dan hardcopy. Materi ini disusun dalam jangka waktu maksimal 2 minggu setelah pelaksanaan koodinasi dilakukan.

c. Pelaksanaan pelatihan. Pelaksanaan pelatihan diikuti oleh Kader PKK di Kelurahan Yosodadi. Lama waktu pelatihan ini 1 hari

d. Evaluasi Kegiatan. Evaluasi kegiatan dilaksanakan sebelum, saat dan setelah pelaksaan kegiatan.

e. Laporan dan Publikasi. Laporan kegiatan ini akan dilaksanakan setelah keberlanjutan Kader PKK dapat berjalan dengan mandiri. Laporan kegiatan ini disusun oleh tim pelaksana dan dipublikasikan pada jurnal terakreditasi.

\section{HASIL DAN PEMBAHASAN}

Kegiatan pengabdian ini dilaksanakan dari akhir Juni 2020 - awal Agustus 2020. Adapun beberapa kegiatan yang dilaksanakan yaitu :

\section{Persiapan}

1. Rapat perencaan awal dilakukan pada tanggal 23 Juni 2020 , yang dihadiri oleh seluruh anggota tim pengabdian bertempat di Kampus FISIP UNILA. 
2. Tahap selanjutnya, masing-masing anggota tim mempersiapkan materi sesuai dengan bidangnya masing-masing.

3. Melakukan pengurusan izin kegiatan pengabdian yang ditujukan kepada Badan Kesatuan Bangsa dan Politik Kota Metro.

4. Setelah mendapatkan izin penelitian dari Kepala Badan Kesatuan Bangsa dan Politik Kota Metro kemudian tim melakukan kontak secara personal kepada Tim Penggerak PKK Kelurahan Yosodadi untuk menyesuaikan jadwal kegiatan yang akhirnya disepakati pada tanggal 2 Agustus 2020 di Aula Sekretariat Posdaya Al Mubarokah Kelurahan Yosodadi, Kota Metro.

5. Tahap akhir, tim pengirimkan surat izin kegiatan kepada Lurah Yosodadi tertanggal 22 Juli 2020.

\section{Pelaksanaan}

Kegiatan pengabdian dilaksanakan pada tanggal 2 Agustus 2020 di Aula Sekretariat Posdaya Al Mubarokah, dengan jumlah peserta yang hadir sebanyak 30 orang. Kegiatan dimulai dengan pembukaan dan acara inti yang dimulai pre-test, pemberian materi dan pelaksanaan post-tes. Secara lengkap susunan acara kegiatan adalah sebagai berikut:

Tabel 2. Susunan Acara Kegiatan

\begin{tabular}{clll}
\hline \multicolumn{1}{c}{ Waktu } & \multicolumn{1}{c}{ Acara } & \multicolumn{1}{c}{ PIC } & \multicolumn{1}{c}{ Ket } \\
\hline $08.00-08.30$ WIB & Persiapan dan Registrasi peserta & Panitia & Daftar hadir \\
$08.30-09.00$ WIB & Pembukaan & Panitia & \\
& Sambutan Ketua Pelaksana & & \\
& Doa & & \\
& Penutup & Panitia & Snack \\
$09.00-09.15$ WIB & Coffe break & Panitia & Soal pre test \\
$09.15-09.30$ WIB & Pre test & Ita Prihantika & \\
$09.30-11.00$ WIB & Materi 1: BAHAYA SAMPAH PLASTIK & Mediya Destalia & \\
$11.00-12.30$ WIB & Materi II: PEMANFAATAN DAN & & \\
& PENGELOLAAN SAMPAH PLASTIK & Panitia & \\
$12.30-13.30$ WIB & Ishoma & Jeni Wulandari & \\
$13.30-14.30$ WIB & Materi III: DAUR ULANG SAMPAH PLASTIK & Hani Damayanti & \\
$14.00-16.00$ WIB & Materi IV: ZERO WASTE, REDUCE, & Aprilia & \\
& REUSE, RECYCLE, REPLACE DAN & & Soal post test \\
\hline
\end{tabular}

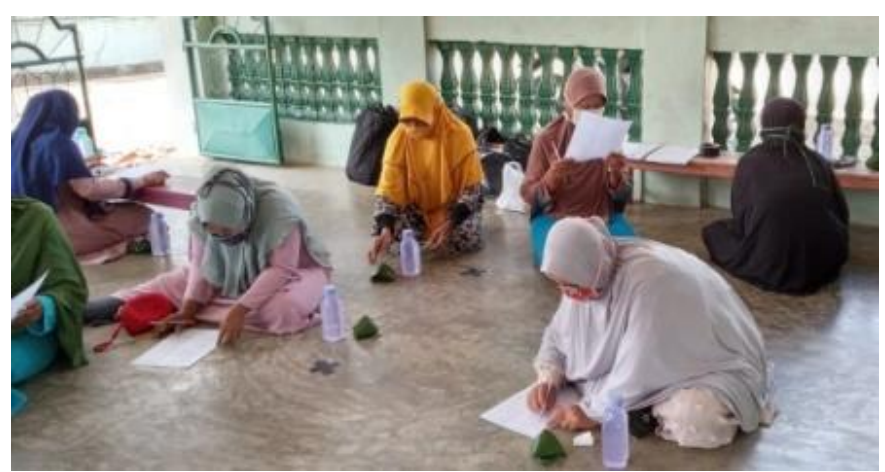

Gambar 1. Pengisian Pre Test oleh Peserta. 
Materi pertama diberikan oleh Ita Prihantika, S.Sos., MA yang berjudul Bahaya Sampah Plastik, yang dikutip dari [6]. Materi disampaikan dengan cara ceramah dan melibatkan peserta untuk memberikan jawaban atau terlibat aktif dalam proses penyampaian materi.

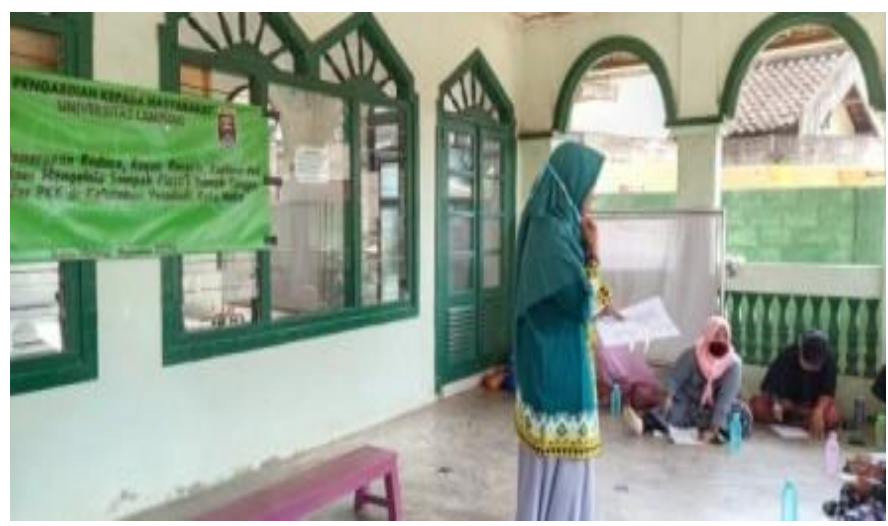

Gambar 2. Pemberian Materi.

Materi kedua masih bersifat teoritis yaitu Pemanfaatan dan Pengelolaan Sampah Plastik oleh Mediya Destalia, yang dikutip dari [7]. Materi ini disampaikan sebagai pembukaan terhadap materi ketiga dan keempat.

Materi ketiga disampaikan oleh Jeni Wulandari dengan judul Daur Ulang Sampah Plastik, yang dikutip dari [8].

Materi ke empat adalah Zero Waste, Reduce, Reuse, Recycle, Replace dan Replant serta Praktik yang disampaikan oleh Hani Damayanti Aprilia, yang dikutip dari [1,9-11]. Pada sesi terakhir ini, peserta diminta untuk aktif berpartisipasi yaitu dengan melakukan praktik dan simulasi. Setelah mendapat tiga materi di awal, pada sesi terakhir ini para peserta diminta untuk membuat ecobrick.

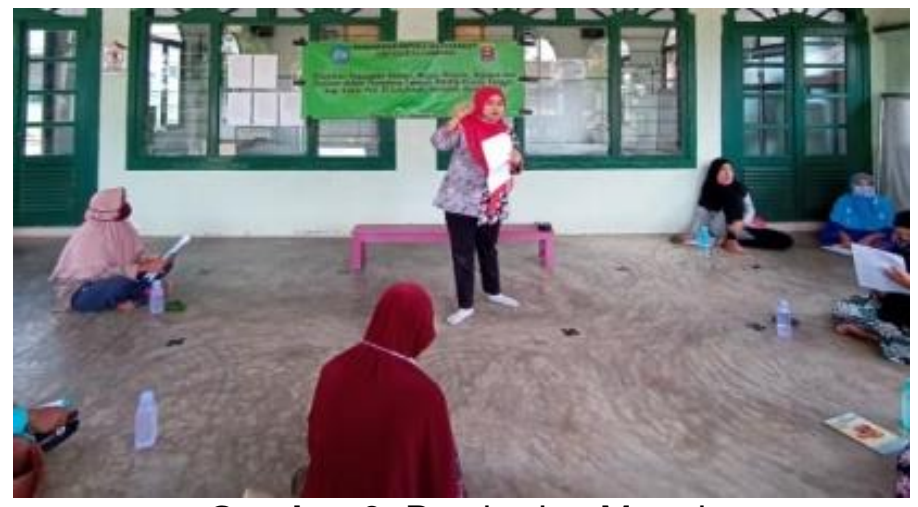

Gambar 3. Pemberian Materi.

Ecobrick adalah mengisi botol plastik dengan sampah plastik hingga padat. Selanjutnya bisa dimanfaatkan untuk blok bangunan dan lain-lain. Bagi para ibu rumah tangga, membuat ecobrick tentu sangat mudah. Sebab ecobrick merupakan salah satu contoh penerapan reduce yang bisa dilakukan mulai dai dapur para ibu. Sampah-sampah dari dapur yang merupakan sampah dari bahan plastik bisa segera dimanfaatkan. Sehingga upaya mengurangi sampah plastik bisa dengan mudah dilakukan. 


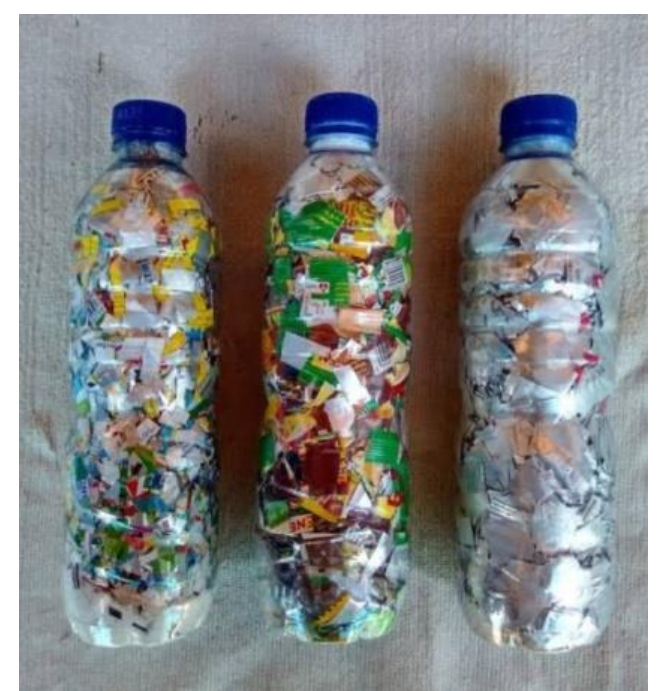

Gambar 4. Ecobrick Hasil Praktik Peserta.

Rangkaian akhir kegiatan diakhiri dengan posttest, dan foto bersama tim pengabdian dan peserta kegiatan.
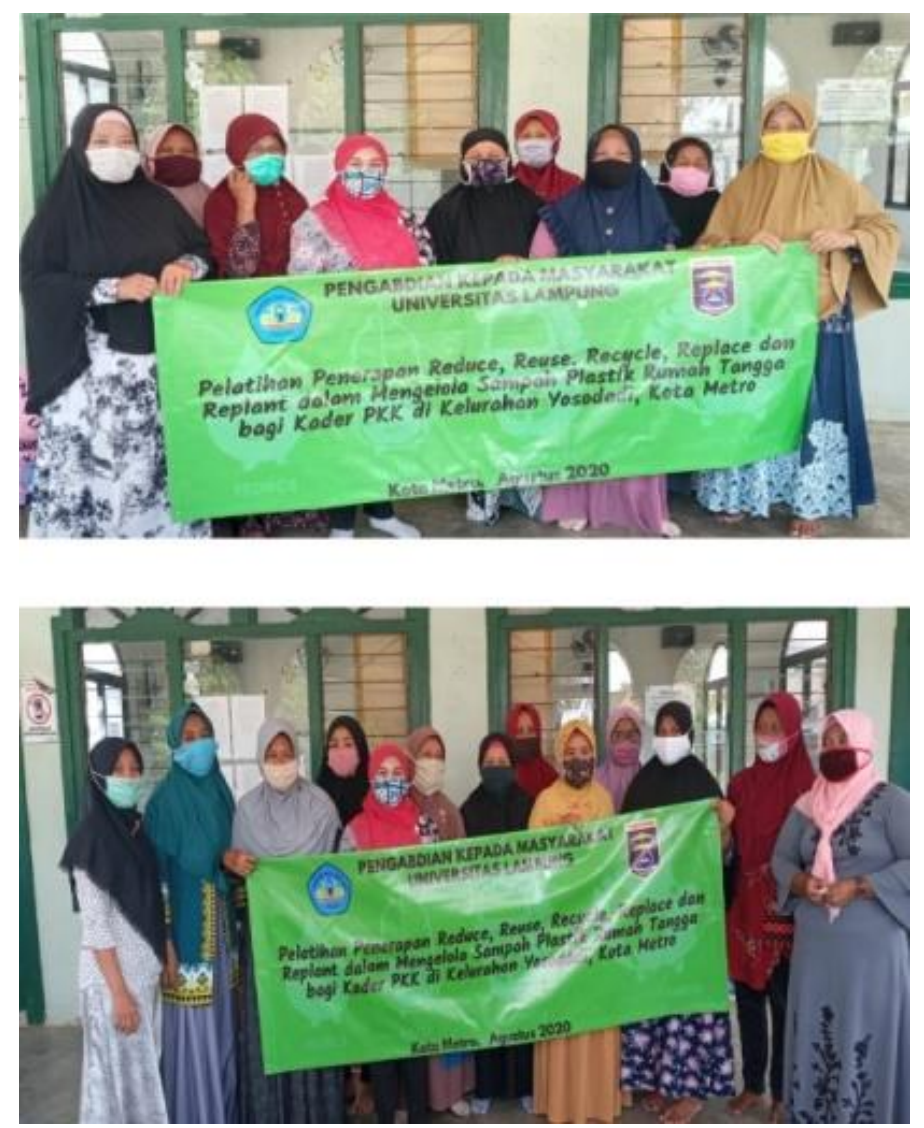

Gambar 5. Foto Tim Pengabdian dan Peserta Kegiatan.

Secara keseluruhan nilai rata-rata peserta sebelum dilaksanakan kegiatan sosialisasi adalah 77,84 dan mengalami kenaikan menjadi 85,96 setelah dilaksanakan kegiatan pelatihan. Kenaikan rata-rata sebesar 8,12 poin. Nilai pre-test tertinggi adalah 100 dan nilai terendah 42, sedangkan untuk sesi post-test nilai tertinggi adalah 100 dan nilai terendah 57. Selengkapnya, hasil pre-test dan post-tes adalah sebagaimana tercantum pada Gambar 6 berikut ini. 


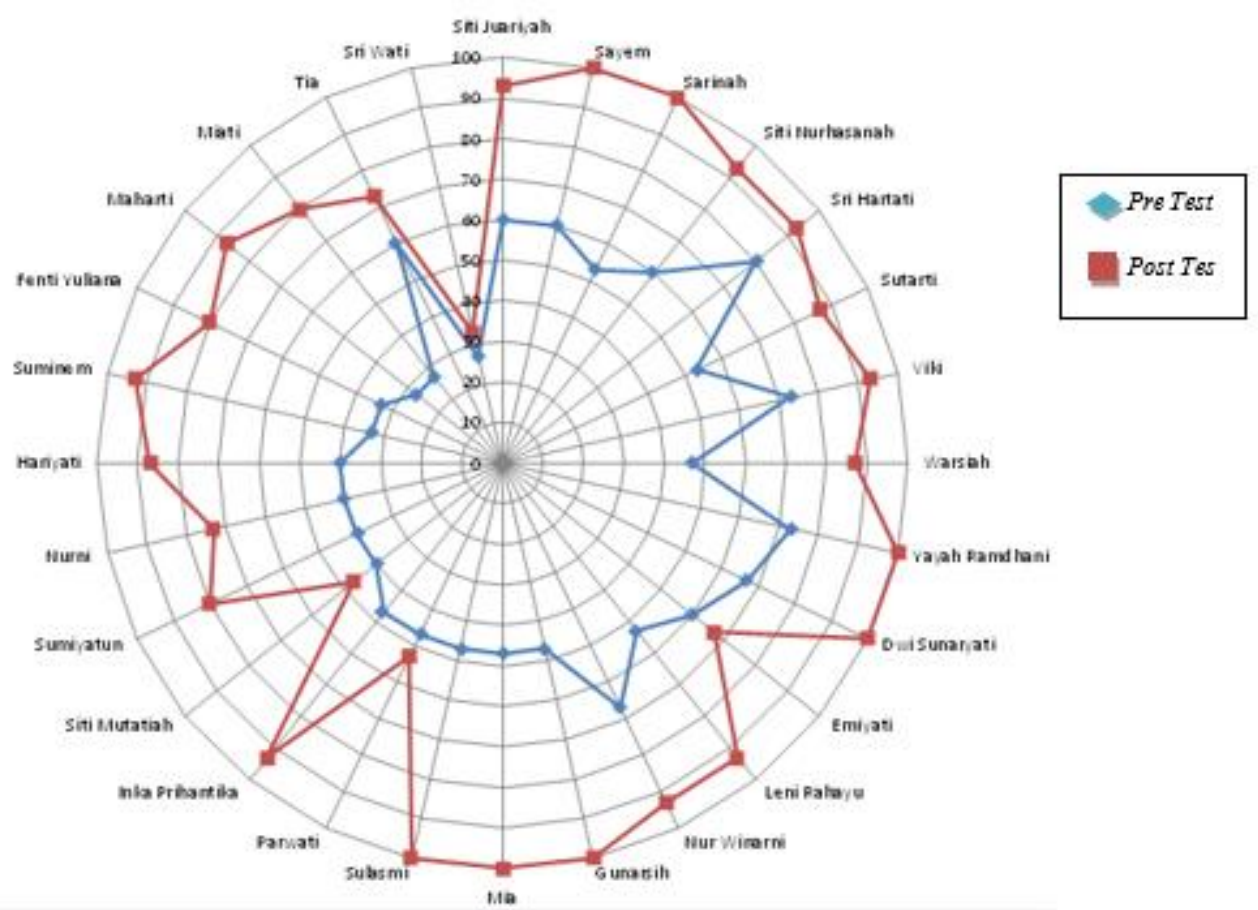

Gambar 6. Hasil Pre dan Post Test Kegiatan

\section{SIMPULAN}

Berdasarkan hasil tersebut diatas maka dapat disimpulkan bahwa kegiatan pengabdian ini mampu memberikan dampak positif secara kognitif terhadap pengetahuan tentang Reduce, Reuse, Recycle, Replace, dan Replant. Sedangkan dari sisi afektif kesadaran, kemauan, dan kemampuan peserta dalam menerapkan konsep Reduce, Reuse, Recycle, Replace, dan Replant dalam mengelola sampah plastik rumah tangga dalam kehidupan sehari-hari.

\section{DAFTAR PUSTAKA}

[1] Prawira, Aditya Eka. (2014). "Sampah di Indonesia Paling Banyak Berasal dari Rumah Tangga" Liputan 6 [Online]. Tersedia: https://m.liputan6.com/health/read/831503/sampah-di-Indonesia-paling-banyakberasal-dari-rumah-tangga. [10 Januari 2020].

[2] Riswan. Sunoko, Henna Rya. dan Hadiyarto, Agus. (2011). Pengelolaan Sampah Rumah Tangga di Kecamatan Daha Selatan. Jurnal Ilmu Lingkungan Vol.9, No. 1, April 2011.

[3] Mawati, Sri. (2009). Partisipasi lbu Rumah Tangga dalam Pengelolaan Sampah Domestik di Kecamatan Semarang Tengah guna Menciptakan Lingkungan yang Sehat. Laporan Penelitian. Semarang: Universitas Diponegoro.

[4] Winarti, Puji. dan Azizah. (2016). Penyuluhan Pengelolaan Sampah Plastik dengan Konsep Zero Waste bagi Ibu Rumah Tangga di Kecamatan Bergas Kabupaten Semarang. Education Pengabdian Kepada Masyarakat. Volume 07 Nomor 01 Maret 2016.

[5] Filmawada, Ziadatum. Hardika. dan Sucipto. (2018). Peran Kader PKK Sebagai Agen Perubahan Kebersihan dan Kesehatan Lingkungan melalui PendampinganProgram Bank Sampah. Jurnal Pendidikan Nonformal Volume 13, No. 2, September 2018.

[6] Levinna dan Paramita, Mindy. (2020). "Waspada Bahaya Sampah Plastik" [Online]. Tersedia: https://skata.info./article/detail/337/waspada-bahaya-sampah-plastik. [10 Juli 2020].

[7] Katadata. (2019). "Pentingnya Pengelolaan Sampah Plastik". Katadata [Online]. Tersedia: https://katadata.co.id/timpublikasikatadata/berita/5e9a4e54bb50f/pentingnya-pengelolaan-sampahplastik. [10 Juli 2020]. 
[8] Siagian, Marahalim. (2020). "Ingin Mendaur Ulang Sampah Plastik Begini Alur Proses yang Benar". Kompasiana [Online]. Tersedia: https://www.kompasiana.com/marahalimsiagian/5e2470de097f365cc125cec2/ingin-mendaur-ulangsampah-plastik-begini-alur-proses-yang-benar?page=7. [10 Juli 2020].

[9] Mawati, Sri. (2009). Partisipasi lbu Rumah Tangga dalam Pengelolaan Sampah Domestik di Kecamatan Semarang Tengah guna Menciptakan Lingkungan yang Sehat. Laporan Penelitian. Semarang: Universitas Diponegoro.

[10] Nisandi, (2007). Pengelolaan Dan Pemanfaatan Sampah Organic Menjadi Briket Arang dan Asap Cair. Prosiding Seminar Nasional Teknologi 2007. Yogyakarta.

[11] Usman, Said. (2016). Strategi Pengelolaan Sampah Rumah Tangga di Kota Tarakan Kalimantan Utara. Jurnal Ekonomi Pembangunan. Vol. 5, No. 3, November 2016. 